\title{
Behavior and Splice Length of Deformed Bars Lapping in Spirally Confined Grout-Filled Corrugated Duct
}

\author{
Yongfeng Zheng $\mathbb{D}^{1},{ }^{1}$ Zhangfeng Zhu $\mathbb{D}^{2},{ }^{2}$ Zhengxing Guo, ${ }^{3}$ and Peng Liu $\mathbb{D}^{4}$ \\ ${ }^{1}$ Key Laboratory of Building Structural Retrofitting and Underground Space Engineering (Shandong Jianzhu University), \\ Ministry of Education, Jinan, Shandong 250101, China \\ ${ }^{2}$ College of Civil Engineering, Nanjing Tech University, Nanjing, Jiangsu 211816, China \\ ${ }^{3}$ School of Civil Engineering, Southeast University, Nanjing, Jiangsu 210096, China \\ ${ }^{4}$ School of Civil Engineering, Central South University, Changsha 410075, China
}

Correspondence should be addressed to Yongfeng Zheng; zhyf-fb@163.com and Peng Liu; lop868@163.com

Received 29 July 2019; Accepted 19 October 2019; Published 11 November 2019

Academic Editor: Michelina Catauro

Copyright ( $) 2019$ Yongfeng Zheng et al. This is an open access article distributed under the Creative Commons Attribution License, which permits unrestricted use, distribution, and reproduction in any medium, provided the original work is properly cited.

\begin{abstract}
This paper discusses the behavior of grouted noncontact lap splices under monotonic tension load. Deformed bars lapped through a grout-filled corrugated duct, and a spiral reinforcement was preembedded in the connection to improve tensile strength of the splice. The experimental results show that bond failure splices are always failed by the pullout of the preembedded bar other than the grouted bar. As the spiral pitch distance is not greater than $75 \mathrm{~mm}$, the tensile strength generally improves with the increment of volumetric spiral reinforcement ratio due to the higher confinement provided by the spiral bar. Compared with the spiral bar diameter, the spiral pitch distance provides more dominant effect on the tensile strength of the connection. Based on the experimental results and the development length specified in ACI 318-14, a revised equation with a reduction factor of 0.76 was proposed to predict the required minimum lap length of spirally confined lap splice.
\end{abstract}

\section{Introduction}

Rebar lapping in grout-filled conduit is enormously used in construction of precast concrete structures. The connection system (Figure 1) is based on the use of consecutive column segments provided each with longitudinal bars protruding from the upper end and corrugated steel conduits encased in the lower end. The steel conduits are positioned adjacent to the embedded longitudinal bars. The continuity of the longitudinal reinforcement is achieved through the noncontact lapping when the lower projecting bars are inserted and grouted into the corrugated duct. In China, the connection of this type is not recommended to be used in primary earthquake-resistant members [1]. Similarly, ACI 318-14 [2] specifies that application of such splices in plastic hinge requires demonstration through laboratory testing that the spliced precast structural element shows an equivalent response to its cast-in-place counterpart.
Research studies to address the aforementioned concerns and the use of grouted noncontact lap splices in plastic hinge regions of structural elements have been completed in recent years. Precast column-to-foundation specimens using grouted corrugated steel conduits were tested under cyclic lateral load combined with axial compression by Belleri and Riva [3] and Popa et al. [4]. Their results indicate that the precast specimens have similar hysteretic response and energy dissipation capacity as the reference monolithic units, and the grouted corrugated ducts are suitable to be used in seismic regions. Rave-Arango et al. [5] prepared a beam-column joint, connecting the steel bars using grouted lap splice at the column ends, and tested under cyclic loading. The data obtained from the test highlighted the seismic behaviors are comparable with cast-in-place unit and just have slight differences in cracking, damage distribution, and hysteretic behavior.

The above test results corroborate the possibility of using the grouted lap splice in seismic regions from the overall 


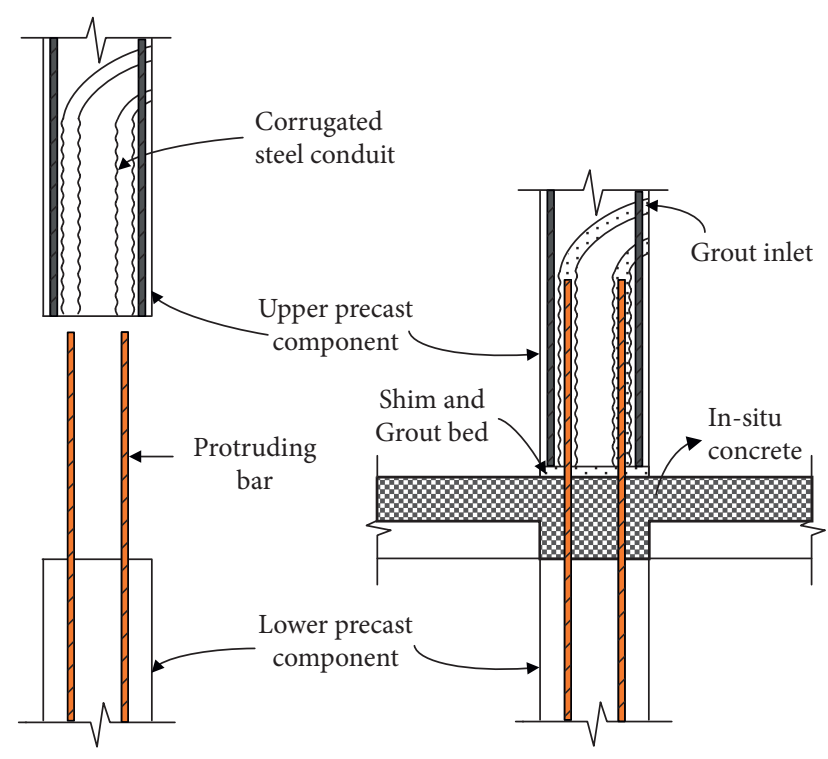

FIgURE 1: Rebar lapping by corrugated steel duct.

seismic response (capacity, hysteretic responses, energy dissipation, etc.) of the precast units. However, for the time being, fewer references exist dealing specifically with the lap length of grouted corrugated duct connection and a calculation method for the required lap length which not only can promise sufficient strength in plastic hinge region, but also is economical, reasonable, and urgently needed. Even so, the following papers could give some enlightenment for the study of this paper. Tullini and Minghini [6] performed an experimental program concerning full-scale tests on precast reinforced concrete column-to-column connections made with the grouted splices. The direct tension test results highlighted the effectiveness of the stress transfer along the splice region, and failure took place outside the bar splice region. The behavior of spirally confined lap splice was investigated by Einea et al. [7] and Hosseini and Rahman [8]. Their investigation shows that the spiral confinement can result in significant reduction of the required lap length. The spiral diameter provides more dominant confining effect compared to the spiral pitch distance [8]. For the conventional lap splice used in cast-inplace concrete structure, Hassan et al. [9] found that the ACI318-08 Building Code provided more conservative bond strength predictions for regular bars compared to larger diameter bars.

Despite the available studies and even the existence of design guidelines that include recommendations for the use of grouted lap splice $[10,11]$, comprehensive experimental characterization of the grouted connection is still scarce, and further work needs to be conducted to provide the test data on which confidence in the design and application of this connection could be built. In response to this, 30 sets of 90 lap splices were prepared, and spiral reinforcement was preembedded in the connected region to improve the bond behavior of the splice. Through monotonic tension test, the effects of spiral configuration on tensile strength were investigated as well as the calculation of the required lap length.

\section{Experimental Program}

2.1. Test Specimens. Experimental parameters include lapping bar diameter, lap length, spiral bar diameter, and spiral pitch distance. The specimens were named with a five component ID according to their variables. Take C40-160.8-6-75 for example; the first part denotes the concrete type (C40), and the second component is the nominal diameter of lapping bar $\left(d_{\mathrm{b}}=16\right.$ or $\left.18 \mathrm{~mm}\right)$, and the third component denotes the ratio $(0.8,1.0$ or 1.2$)$ of the lap length $\left(l_{\text {,exp }}\right)$ to the basic development length $\left(l_{\mathrm{aE}}\right)$. The value of $l_{\mathrm{aE}}$ can be defined by GB 50010-2010 [12], as follows:

$$
l_{\mathrm{aE}}=\zeta_{\mathrm{aE}} \zeta_{\mathrm{a}} \alpha \frac{f_{\mathrm{by}}}{f_{\mathrm{t}}} d_{\mathrm{b}} \approx 30 d_{\mathrm{b}},
$$

where $\zeta_{\mathrm{aE}}$ is a correction factor reflecting the building aseismic grade, $\zeta_{\mathrm{aE}}=1.05 ; \zeta_{\mathrm{a}}$ is a factor reflecting the effects of reinforcement size, epoxy coating, concrete cover, etc, $\zeta_{\mathrm{a}}=1.00 ; \alpha$ is the reinforcement shape factor, $\alpha=0.14 ; f_{\mathrm{by}}$ is the design tensile strength of reinforcement, $f_{\mathrm{by}}=360 \mathrm{MPa} ; f_{\mathrm{t}}$ is the design tensile strength of concrete, $f_{\mathrm{t}}=1.71 \mathrm{MPa}$. The fourth part in the specimen ID illustrates the nominal bar diameter of spiral reinforcement $\left(d_{\mathrm{sb}}=4\right.$ or $\left.6 \mathrm{~mm}\right)$. The last part indicates the pitch distance of the spiral $\left(s_{\mathrm{v}}=50,75\right.$ or $100 \mathrm{~mm}$ ). For each test type, three identical specimens were prepared.

Configuration and dimensions of the test specimens are shown in Figure 2. Each specimen consisted of a concrete block having a rectangular cross section of $120 \times 150 \mathrm{~mm}$. To prevent any additional restraints, an unbonded length of $25 \mathrm{~mm}$ was provided at the end of the block using a plastic tube. The spiral diameters $\left(D_{\mathrm{s}}\right)$ used in the specimens for $16 \mathrm{~mm}$ and $18 \mathrm{~mm}$ bar splices were $65 \mathrm{~mm}$ and $70 \mathrm{~mm}$, respectively. All the reserved conduits were formed by corrugated metal ducts with the same diameter of $40 \mathrm{~mm}$.

2.2. Test Setup. Different from butt splice, the lap splice is eccentrically loaded when tested on a traditional mechanical testing machine due to the eccentric position of the lapping bar in the concrete block and consequently affects the accuracy of test values inevitably. Therefore, a tension test setup was specially developed, as shown in Figure 3. The support frame is mainly composed of four screws of $45 \mathrm{~mm}$ in diameter and three steel plates of $16 \mathrm{~mm}$ in thickness. Three plates are welded to each other and formed into a trough structure used for placing the test specimen. Meanwhile, there are steel plates of $40 \mathrm{~mm}$ in thickness at each side of the frame, and an eccentric hole was drilled in the plate to be passed through by the lapping bar. As the bar loaded, the $40 \mathrm{~mm}$ thick plate can provide enough reaction force to ensure the lapping bar fractured. In order to reduce friction between the inner wall of the frame and the concrete block, PTFE plates were placed on both sides and bottom of the steel trough. Two hydraulic centre hole jacks were used to provide monotonic tension load. Before test, the jacks and load cell were calibrated on a universal material testing machine. After curing for 28 days, all the specimens were tested under incremental tensile load at a rate of $2 \mathrm{MPa} / \mathrm{s}$. 

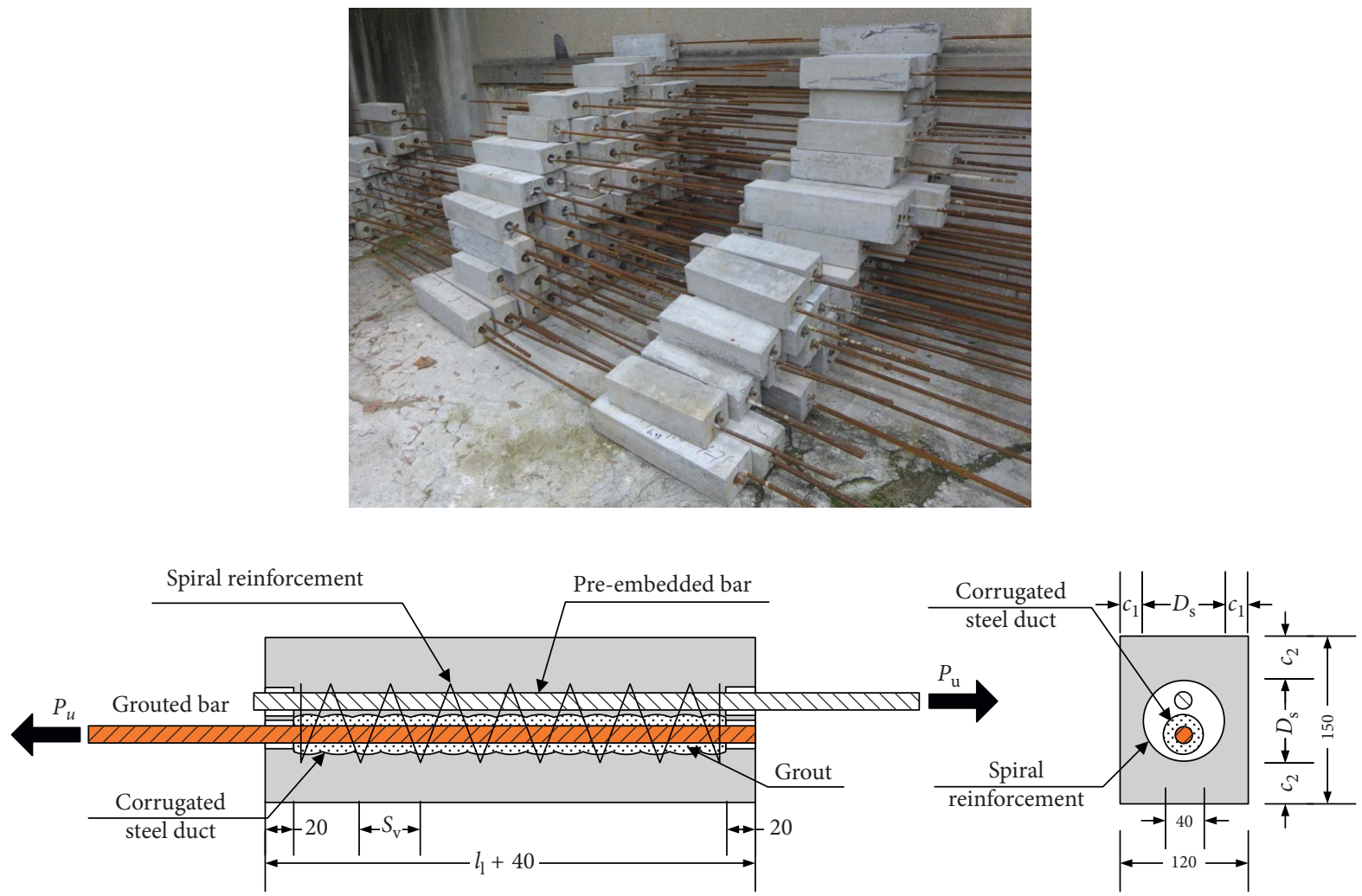

FIgURE 2: Configuration of splice specimen (unit: $\mathrm{mm}$ ).
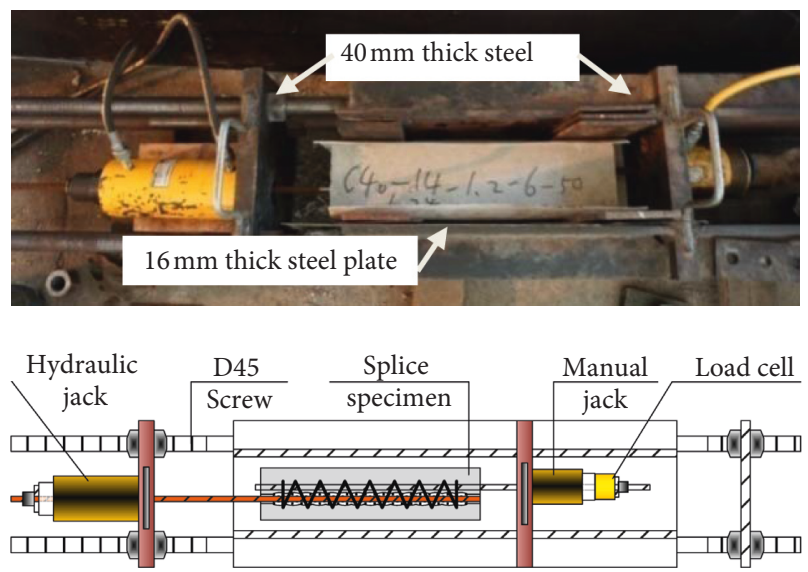

FIgure 3: Test setup.

During the test, the tension load was recorded by the pressure value of the oil pressure gauge and the readings of the load cell.

2.3. Material. The concrete was supplied by a commercial ready mixing plant. The concrete type was $\mathrm{C} 40$ (that is, with a specified 28-day cubic and prism compressive strength greater than $40.0 \mathrm{MPa}$ and $26.8 \mathrm{MPa}$, respectively). The test compressive strength, which was determined at the day of testing the lap splice specimens using $100 \times 100 \times 300 \mathrm{~mm}$ prisms cast at the same time as the specimens and cured alongside the specimens, is $27.2 \mathrm{MPa}$.
High-strength nonshrinkage grout was used as filler material pumped into the corrugated duct. The grout was prepared with a mix of $0.13 \mathrm{~kg}$ of dry powder in 1 liter of water. The average compressive and flexural strengths at the day of testing were $80.5 \mathrm{MPa}$ and $11.1 \mathrm{MPa}$, respectively.

Two different deformed bar diameters were used in this experimental program with the same specified yield strength $f_{\text {byk }}$ of $400 \mathrm{MPa}$ and tensile strength $f_{\text {buk }}$ of $540 \mathrm{MPa}$ (steel bar grade: HRB400). Tension verification tests were conducted with specimens that were cut from the same batch reinforcements as the ones used in the pullout tests. The average mechanical properties are listed in Table 1.

\section{Experimental Results}

3.1. Failure Mode. Two failure modes were observed, namely, bar fracture failure and bar pullout failure. In comparison with the bond failure of bar pullout, specimen failed by bar fracture is the desired failure mode for the better reliability. Taking C40-18-1.0-6-75 as an example, the cracking pattern is described as follows: first transverse crack occurred in the middle of concrete block when the specimen was loaded to about $60 \mathrm{kN}$; as the tension load increased to about $100 \mathrm{kN}$, two cracks were observed at both ends of the block; at approximately $107 \mathrm{kN}$, the bar yielded, and subsequently more and more splitting cracks initiated from the corner of the block; as the load increased to about $156 \mathrm{kN}$, the lapping bar fractured or pulled out accompanied with spalling of the corner concrete, as shown in Figure 4(a). For the pullout failure specimens of $18 \mathrm{~mm}$ bar, in addition to 
TABLe 1: Properties of reinforcing steel bars (average value of three specimens).

\begin{tabular}{lcccc}
\hline Diameter $d_{\mathrm{b}}(\mathrm{mm})$ & Actual yield strength $(\mathrm{MPa})$ & Actual tensile strength $(\mathrm{MPa})$ & Elongation rate $(\%)$ & Elastic modulus $(\mathrm{MPa})$ \\
\hline 16 & 430 & 603 & 25.3 & $2.0 \times 10^{5}$ \\
18 & 425 & 615 & 24.9 & $2.0 \times 10^{5}$ \\
\hline
\end{tabular}

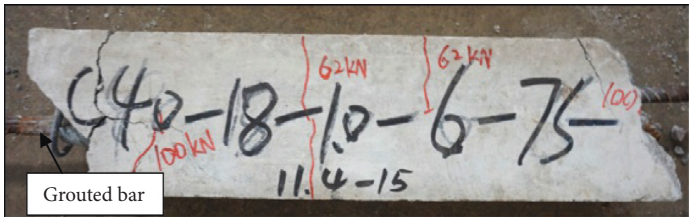

(a)

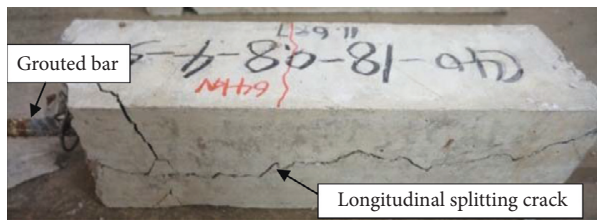

(b)

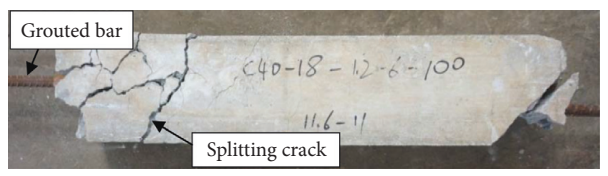

(c)

FIgURE 4: Typical cracking after load. (a) C40-18-1.0-6-75. (b) C40-18-0.8-4-50. (c) C40-18-1.2-6-100.

the transverse splitting cracks, longitudinal cracks also can be observed after the bar yielding in the side concrete surface (Figure 4(b)).

It is important to stress that all the bond failure specimens failed by the pullout of preembedded bar other than the grouted bar. This indicates a higher bond strength of grouted bar and can be attributed to the following: (i) the strength of filler grout in metal corrugated duct is greatly higher than the surrounding concrete and (ii) the steel duct provides uniform confining stresses on the grout splitting dilation. Therefore, the tensile strength of lap splice is controlled by the bond strength of the preembedded bar, and the grouted bar, filler grout, and corrugated duct can be assumed as a single body. Consequently, more splitting cracks are generated on the side of grouted bar due to the relatively smaller concrete cover, as shown in Figure 4(c).

Table 2 summarizes the test results of all the specimens. With the exception of specimens C40-18-0.8-6-100, all specimens sustained maximum axial stresses, higher than 125 percent of the specified strength $f_{\text {byk }}$ of lapping bars and, in most cases, no less than 150 percent of $f_{\text {byk }}$. As the bar diameter increases from $16 \mathrm{~mm}$ to $18 \mathrm{~mm}$, the number of pullout failure specimens increases from $33.3 \%$ to $73.3 \%$, and a more significant effect of the spiral reinforcement on the tensile strength of the splice can be observed. The minimum lap lengths to ensure bar fracture are $24 d_{\mathrm{b}}$ and $30 d_{\mathrm{b}}$, respectively, for the $16 \mathrm{~mm}$ and $18 \mathrm{~mm}$ bar splices with the spiral bar diameter $\left(d_{\mathrm{sb}}\right)$ of $6 \mathrm{~mm}$ and pitch distance $\left(s_{\mathrm{v}}\right)$ of 50 (hereafter denoted as d6@50 and similarly to the other spiral configuration). For the specimens with the spiral of $\mathrm{d} 4 @ 75$, however, the minimum lap lengths are $36 d_{\mathrm{b}}$ and $>36 d_{\mathrm{b}}$, respectively.

3.2. Strength of Lap Splice. Figures 5 and 6 show the tensile strength $\left(f_{\mathrm{u}}\right)$ and bond strength $\left(\tau_{\mathrm{b}}\right)$ versus lap length $\left(l_{1}\right)$, respectively. The average bond strength can be calculated by equation (2). Considering that the tensile strength of the bar fracture specimen is determined by the strength of the lapping bar, which cannot reflect the effects of the lap length, only bond failure specimens are presented. From Figure 5, nonlinear increment of the tensile strength with the increase of lap length can be noted. As the lap length increases from $0.8 l_{\mathrm{aE}}$ to $1.0 l_{\mathrm{aE}}$, the tensile strength increases significantly and averagely by $10.9 \%$. However, as the length increases from $1.0 l_{\mathrm{aE}}$ to $1.2 l_{\mathrm{aE}}$, the strength increases slightly only by $2.3 \%$. On the other hand, different from the variation of the tensile strength, the bond strength of lapping bar decreases averagely by $24.3 \%$ as the lap length increases from $0.8 l_{\mathrm{aE}}$ to $1.2 l_{\mathrm{aE}}$, as shown in Figure 6. By virtue of more ribs on the bar engaged to interlock with surrounding concrete, the tensile strength increases with the lap length. But due to the nonuniform distribution of the bond stress at bar-concrete interface, the tensile strength does not increase linearly. Meanwhile, longer bonded length creates a more apparent uneven bond stress distribution $[13,14]$ and a larger number of primary cracks within the lap length [15], and hence, lower bond strength is generated.

$$
\tau_{\mathrm{b}}=\frac{P_{\mathrm{u}, \exp }}{\left(\pi d_{\mathrm{b}} l_{1}\right)}=\frac{0.25 f_{\mathrm{u}} d_{\mathrm{b}}}{l_{1}}
$$

In addition, Figure 5 also illustrates the effects of configurations of the spiral reinforcement on the tensile strength of the splice. The specimens with the spiral of d6@75 give the highest strength, and followed by d4@50,d4@75, and d6@ 100 , in turn decrease. In order to see the effects of the spiral configuration graphically, the variation of tensile strength with different volumetric spiral reinforcement ratio $\left(\rho_{\mathrm{sv}}\right)$ is plotted in Figure 7. The ratio can be used to appraise the amount of spiral reinforcement, which is calculated by equation (3) $[2,12]$. Results show that increasing the volumetric ratio can generally improve the bond strength, and more apparent influence can be observed by the specimens with greater bar diameter and shorter lap length. For example, in the case of splice with bar diameter of $18 \mathrm{~mm}$ and 
TABLE 2: Summary of test results.

\begin{tabular}{|c|c|c|c|c|}
\hline Specimens & $\begin{array}{c}f_{\mathrm{u}} \\
(\mathrm{MPa})\end{array}$ & Average (MPa) & $\begin{array}{c}f_{\mathrm{u}} / \\
f_{\text {byk }}\end{array}$ & $\begin{array}{l}\text { Failure } \\
\text { mode* }\end{array}$ \\
\hline \multirow{3}{*}{ C40-16-0.8-6-100 } & 543.1 & \multirow{3}{*}{548.1} & 1.36 & $\mathrm{BP}$ \\
\hline & 543.5 & & 1.36 & $\mathrm{BP}$ \\
\hline & 557.8 & & 1.39 & $\mathrm{BP}$ \\
\hline \multirow{3}{*}{ C40-16-0.8-6-75 } & 600.1 & \multirow{3}{*}{598.1} & 1.50 & $\mathrm{BF}$ \\
\hline & 598.5 & & 1.50 & $\mathrm{BP}$ \\
\hline & 595.8 & & 1.49 & $\mathrm{BP}$ \\
\hline \multirow{3}{*}{ C40-16-0.8-6-50 } & 604.3 & \multirow{3}{*}{604.3} & 1.51 & $\mathrm{BF}$ \\
\hline & 610.6 & & 1.53 & $\mathrm{BF}$ \\
\hline & 598.0 & & 1.50 & $\mathrm{BF}$ \\
\hline \multirow{3}{*}{ C40-16-0.8-4-75 } & 579.3 & \multirow{3}{*}{579.3} & 1.45 & $\mathrm{BF}$ \\
\hline & 582.5 & & 1.46 & $\mathrm{BP}$ \\
\hline & 576.1 & & 1.44 & $\mathrm{BP}$ \\
\hline \multirow{3}{*}{ C40-16-0.8-4-50 } & 602.3 & \multirow{3}{*}{598.0} & 1.51 & $\mathrm{BF}$ \\
\hline & 593.6 & & 1.48 & $\mathrm{BP}$ \\
\hline & 598.1 & & 1.50 & $\mathrm{BF}$ \\
\hline \multirow{3}{*}{ C40-16-1.0-6-100 } & 576.3 & \multirow{3}{*}{572.5} & 1.44 & $\mathrm{BP}$ \\
\hline & 560.4 & & 1.40 & $\mathrm{BP}$ \\
\hline & 580.7 & & 1.45 & $\mathrm{BP}$ \\
\hline \multirow{3}{*}{ C40-16-1.0-6-75 } & 599.1 & \multirow{3}{*}{601.5} & 1.50 & $\mathrm{BF}$ \\
\hline & 600.6 & & 1.50 & $\mathrm{BP}$ \\
\hline & 604.7 & & 1.51 & $\mathrm{BF}$ \\
\hline \multirow{3}{*}{ C40-16-1.0-6-50 } & 613.0 & \multirow{3}{*}{606.7} & 1.53 & $\mathrm{BF}$ \\
\hline & 608.9 & & 1.52 & $\mathrm{BF}$ \\
\hline & 598.1 & & 1.50 & $\mathrm{BF}$ \\
\hline \multirow{3}{*}{ C40-16-1.0-4-75 } & 599.6 & \multirow{3}{*}{590.7} & 1.50 & $\mathrm{BF}$ \\
\hline & 591.2 & & 1.48 & $\mathrm{BP}$ \\
\hline & 581.3 & & 1.45 & $\mathrm{BP}$ \\
\hline & 603.3 & & 1.51 & $\mathrm{BF}$ \\
\hline C40-16-1.0-4-50 & 598.1 & 603.4 & 1.50 & BP \\
\hline & 608.7 & & 1.52 & $\mathrm{BF}$ \\
\hline & 604.8 & & 1.51 & $\mathrm{BF}$ \\
\hline C40-16-1.2-6-100 & 609.1 & 606.0 & 1.52 & $\mathrm{BF}$ \\
\hline & 604.1 & & 1.51 & $\mathrm{BF}$ \\
\hline & 611.8 & & 1.53 & $\mathrm{BF}$ \\
\hline C40-16-1.2-6-75 & 603.6 & 607.7 & 1.51 & $\mathrm{BF}$ \\
\hline & 607.7 & & 1.52 & $\mathrm{BF}$ \\
\hline & 598.0 & & 1.50 & $\mathrm{BF}$ \\
\hline C40-16-1.2-6-50 & 605.0 & 601.2 & 1.51 & $\mathrm{BF}$ \\
\hline & 600.5 & & 1.50 & $\mathrm{BF}$ \\
\hline & 598.3 & & 1.50 & $\mathrm{BF}$ \\
\hline C40-16-1.2-4-75 & 607.1 & 602.2 & 1.52 & $\mathrm{BF}$ \\
\hline & 601.1 & & 1.50 & $\mathrm{BF}$ \\
\hline & 598.0 & & 1.50 & $\mathrm{BF}$ \\
\hline C40-16-1.2-4-50 & 603.6 & 600.6 & 1.51 & $\mathrm{BF}$ \\
\hline & 600.3 & & 1.50 & $\mathrm{BF}$ \\
\hline & 509.8 & & 1.27 & $\mathrm{BP}$ \\
\hline C40-18-0.8-6-100 & 495.4 & 495.7 & 1.24 & $\mathrm{BP}$ \\
\hline & 481.8 & & 1.20 & $\mathrm{BP}$ \\
\hline & 561.9 & & 1.40 & $\mathrm{BP}$ \\
\hline C40-18-0.8-6-75 & 598.0 & 575.8 & 1.50 & $\mathrm{BP}$ \\
\hline & 567.6 & & 1.42 & $\mathrm{BP}$ \\
\hline & 613.1 & & 1.53 & $\mathrm{BF}$ \\
\hline C40-18-0.8-6-50 & 601.9 & 604.0 & 1.50 & $\mathrm{BP}$ \\
\hline & 598.1 & & 1.50 & $\mathrm{BP}$ \\
\hline & 518.2 & & 1.30 & $\mathrm{BP}$ \\
\hline C40-18-0.8-4-75 & 523.1 & 520.6 & 1.31 & $\mathrm{BP}$ \\
\hline & 520.6 & & 1.30 & $\mathrm{BP}$ \\
\hline
\end{tabular}

TABle 2: Continued.

\begin{tabular}{|c|c|c|c|c|}
\hline Specimens & $\begin{array}{c}f_{\mathrm{u}} \\
(\mathrm{MPa})\end{array}$ & Average (MPa) & $\begin{array}{l}f_{\mathrm{u}} / \\
f_{\text {byk }}\end{array}$ & $\begin{array}{l}\text { Failure } \\
\text { mode* }\end{array}$ \\
\hline \multirow{3}{*}{ C40-18-0.8-4-50 } & 543.5 & \multirow{3}{*}{544.7} & 1.36 & $\mathrm{BP}$ \\
\hline & 535.7 & & 1.34 & $\mathrm{BP}$ \\
\hline & 555.0 & & 1.39 & $\mathrm{BP}$ \\
\hline \multirow{3}{*}{ C40-18-1.0-6-100 } & 582.9 & \multirow{3}{*}{573.5} & 1.46 & $\mathrm{BP}$ \\
\hline & 559.2 & & 1.40 & BP \\
\hline & 578.4 & & 1.45 & $\mathrm{BP}$ \\
\hline \multirow{3}{*}{ C40-18-1.0-6-75 } & 619.9 & \multirow{3}{*}{613.9} & 1.55 & $\mathrm{BF}$ \\
\hline & 607.5 & & 1.52 & $\mathrm{BP}$ \\
\hline & 614.2 & & 1.54 & $\mathrm{BP}$ \\
\hline \multirow{3}{*}{ C40-18-1.0-6-50 } & 614.6 & \multirow{3}{*}{614.5} & 1.54 & $\mathrm{BF}$ \\
\hline & 618.7 & & 1.55 & $\mathrm{BF}$ \\
\hline & 610.3 & & 1.53 & $\mathrm{BF}$ \\
\hline \multirow{3}{*}{ C40-18-1.0-4-75 } & 570.1 & \multirow{3}{*}{584.7} & 1.43 & $\mathrm{BP}$ \\
\hline & 580.9 & & 1.45 & $\mathrm{BP}$ \\
\hline & 603.1 & & 1.51 & $\mathrm{BP}$ \\
\hline \multirow{3}{*}{ C40-18-1.0-4-50 } & 589.4 & \multirow{3}{*}{593.4} & 1.47 & $\mathrm{BP}$ \\
\hline & 598.0 & & 1.50 & $\mathrm{BP}$ \\
\hline & 592.8 & & 1.48 & $\mathrm{BP}$ \\
\hline \multirow{3}{*}{ C40-18-1.2-6-100 } & 601.5 & \multirow{3}{*}{592.0} & 1.50 & $\mathrm{BP}$ \\
\hline & 594.3 & & 1.49 & $\mathrm{BP}$ \\
\hline & 580.2 & & 1.45 & $\mathrm{BP}$ \\
\hline \multirow{3}{*}{ C40-18-1.2-6-75 } & 620.5 & \multirow{3}{*}{617.7} & 1.55 & $\mathrm{BF}$ \\
\hline & 615.7 & & 1.54 & $\mathrm{BF}$ \\
\hline & 616.9 & & 1.54 & $\mathrm{BP}$ \\
\hline \multirow{3}{*}{ C40-18-1.2-6-50 } & 619.2 & \multirow{3}{*}{620.5} & 1.55 & $\mathrm{BF}$ \\
\hline & 625.5 & & 1.56 & $\mathrm{BF}$ \\
\hline & 616.8 & & 1.54 & $\mathrm{BF}$ \\
\hline \multirow{3}{*}{ C40-18-1.2-4-75 } & 588.3 & \multirow{3}{*}{594.4} & 1.47 & $\mathrm{BP}$ \\
\hline & 593.1 & & 1.48 & $\mathrm{BP}$ \\
\hline & 601.9 & & 1.50 & $\mathrm{BP}$ \\
\hline \multirow{3}{*}{ C40-18-1.2-4-50 } & 608.1 & \multirow{3}{*}{615.6} & 1.52 & $\mathrm{BF}$ \\
\hline & 618.1 & & 1.55 & $\mathrm{BF}$ \\
\hline & 620.7 & & 1.55 & $\mathrm{BP}$ \\
\hline
\end{tabular}

${ }^{*} \mathrm{BF}$ represents bar fracture failure; BP represents bar pullout failure.

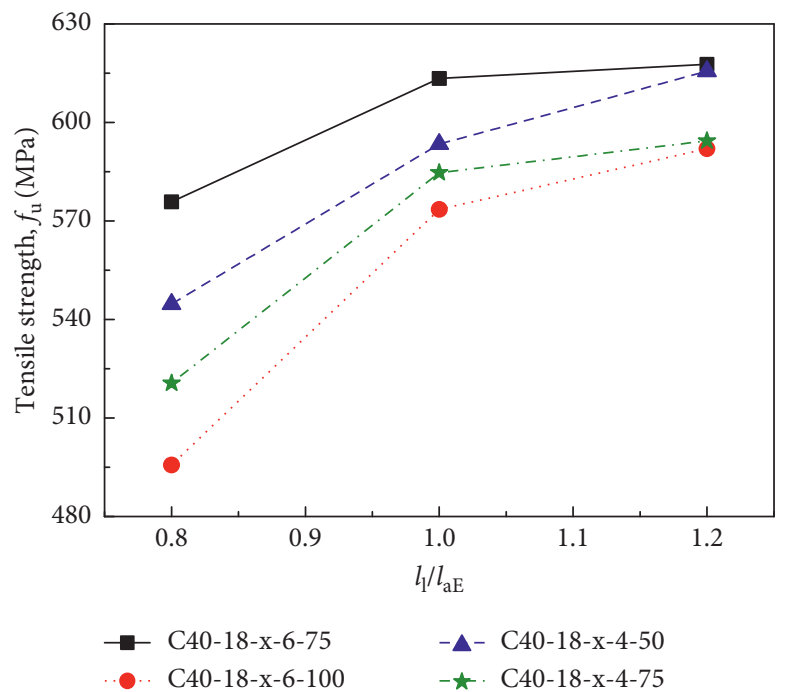

Figure 5: Tensile strength-lap length relationship. 


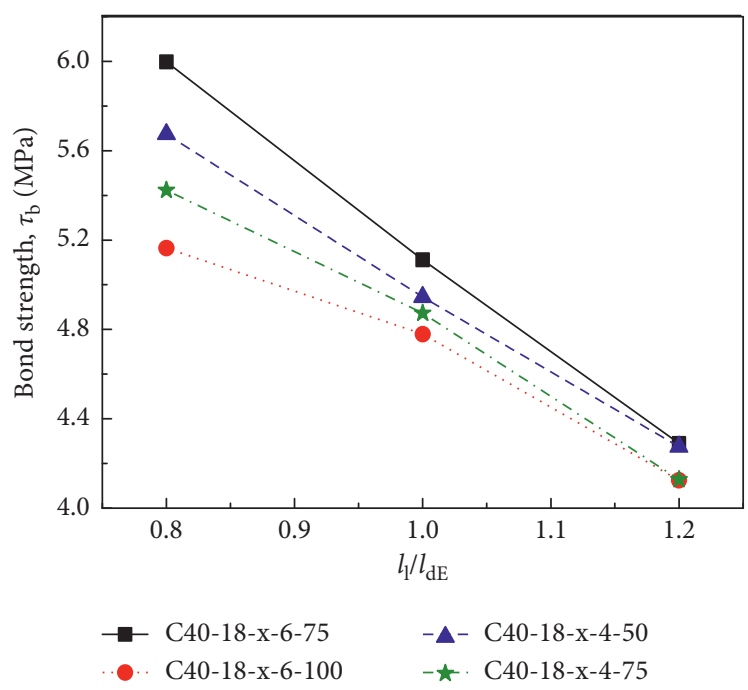

FIgURE 6: Bond strength-lap length relationship.

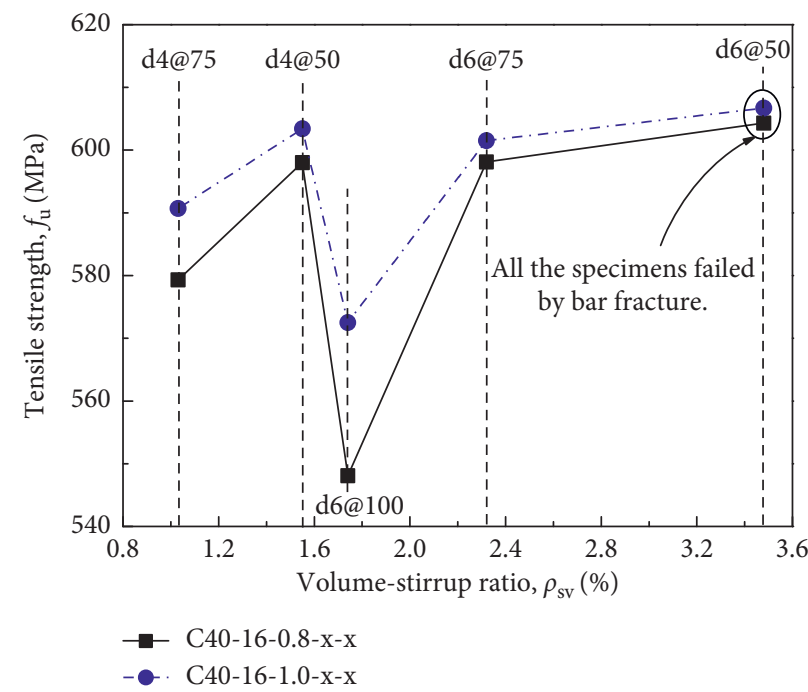

(a)

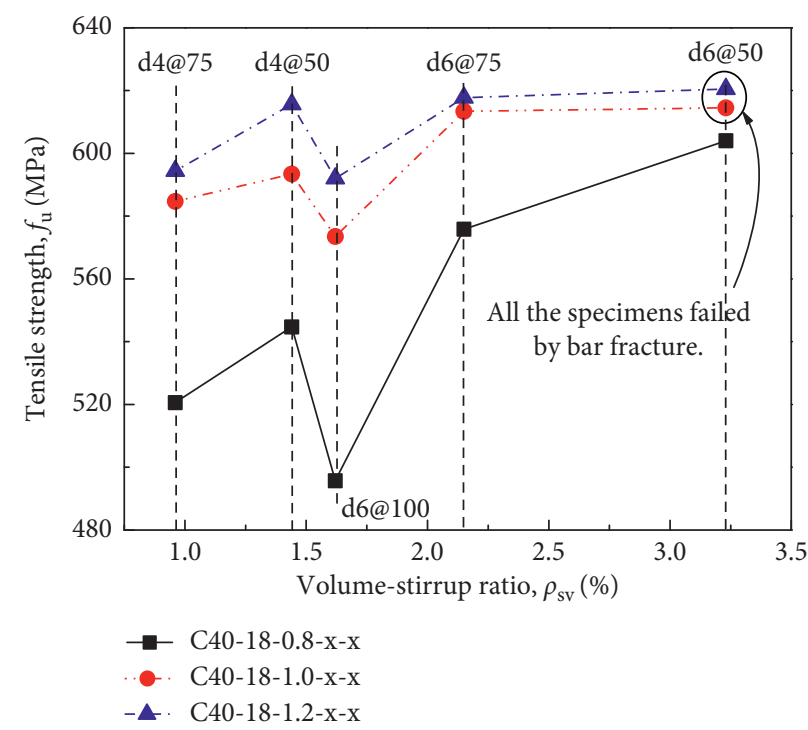

(b)

FIGURE 7: Tensile strength-volume stirrup ratio relationship: (a) d16; (b) d18.

lap length of $0.8 l_{\mathrm{d}}$, by increasing the ratio of $\rho_{\text {sv }}$ from $0.96 \%$ (d4@75) to 3.23\% (d6@50), the tensile strength improves dramatically from 520.6 MPa to $604.0 \mathrm{MPa}$.

It should be noted that all the family curves have a distinct turning point at the abscissa value of $1.74 \%$ for $16 \mathrm{~mm}$ bar splices and $1.62 \%$ for $18 \mathrm{~mm}$ bar splices. The two troughs represent the spiral configuration of d6@100. Spiral pitch distance taken as $100 \mathrm{~mm}$ seems too be great to be used for application in practice. Meanwhile, comparing d4@50 with $\mathrm{d} 6 @ 75$, although the ratio of $\rho_{\mathrm{sv}}$ increases by $45 \%$, no significant improvement in tensile strength can be observed. For the $18 \mathrm{~mm}$ bar splices, the tensile strength is only improved by an average of $3.1 \%$, and for the $16 \mathrm{~mm}$ one, the tensile strength even slightly decreases. These results may infer that compared to increasing the diameter of the spiral bar, it is more effective to improve the tensile strength through reducing the pitch distance. The following sections will make further analysis on the effect of the spiral configuration.

$$
\rho_{\mathrm{sv}}=\frac{\left(0.25 \pi d_{\mathrm{sb}}^{2} \cdot \pi D_{\mathrm{s}}\right)}{\left(0.25 \pi D_{\mathrm{s}}^{2} \cdot s_{\mathrm{v}}\right)}=\frac{\pi d_{\mathrm{sb}}^{2}}{\left(D_{\mathrm{s}} s_{\mathrm{v}}\right)}
$$

\section{Confining Mechanism of Spirally Confined Lap Splice}

The effect of spiral reinforcement on the bond strength can be explained by a free body diagram shown in Figure 8 . Considering that all the bond failure splices failed by pullout of the preembedded bars, the interactions between the grouted bar, filler grout, and metal corrugated duct are 


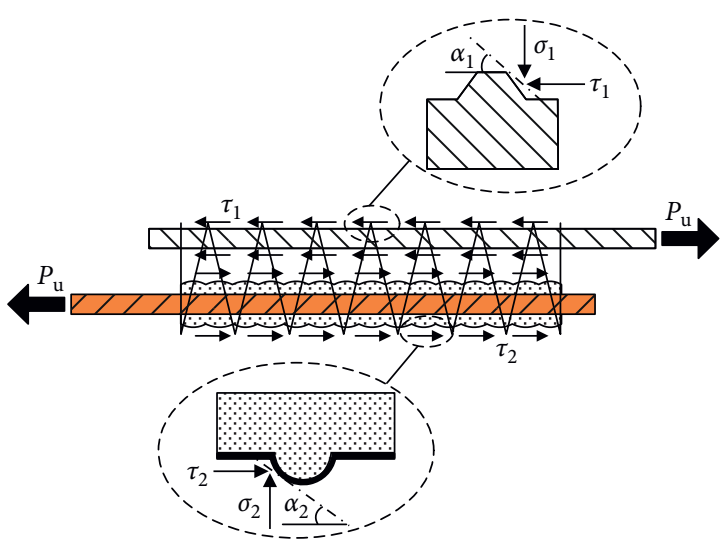

(a)

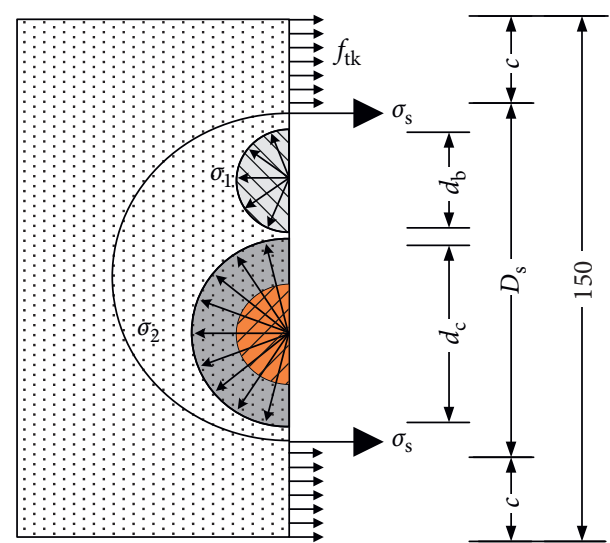

(b)

Figure 8: Free body diagram. (a) Axial forces equilibrium. (b) Hoop forces equilibrium.

ignored, and the three components are deemed as a single body in the figure.

Under direct tension load, the bar rib bearing actions against the concrete occur, as seen in Figure 8(a). These bearing actions can be divided into tangential stress $\left(\tau_{1}\right)$ and normal stress $\left(\sigma_{1}\right)$, similarly to the interaction between the corrugated duct and the concrete. The normal stresses which cause radial cracks in concrete have been confined effectively by the spiral reinforcement, and consequently creates tensile stress in the spiral, as seen in Figure 8(b). The following equations can be driven from the equilibrium of axial and hoop forces:

$$
\begin{aligned}
P_{\mathrm{u}} & =0.25 f_{\mathrm{u}} \pi d_{\mathrm{b}}^{2}=\pi \tau_{1} d_{\mathrm{b}} l_{\mathrm{l}}, \\
f_{\mathrm{tk}} c s_{\mathrm{v}}+0.5 \pi \sigma_{\mathrm{s}} d_{\mathrm{sb}}^{2} & =\left(\sigma_{1} d_{\mathrm{b}}+\sigma_{2} d_{\mathrm{c}}\right) s_{\mathrm{v}} \\
\tau_{1} d_{\mathrm{b}} & =\tau_{2} d_{\mathrm{c}} \\
\tau_{1} & =\sigma_{1} \tan \alpha_{1} \\
\tau_{2} & =\sigma_{2} \tan \alpha_{2},
\end{aligned}
$$

where $d_{\mathrm{c}}$ is diameter of corrugated duct; $s_{\mathrm{v}}$ is spiral pitch distance; $c$ is the smaller thickness of the concrete cover $\left(c_{1}\right.$ or $c_{2}$ in Figure 2); $d_{\mathrm{sb}}$ is diameter of the spiral bar. With the increase of tension load, the ribs of steel bar and metal conduit can crush the surrounding concrete by wedging action. When the concrete is crushed into a compacted powder, it becomes lodged in front of the ribs [16]. This in effect produces ribs with face angles of about $45^{\circ}$, i.e., $\alpha_{1}=\alpha_{2}=45^{\circ}$. Consequently, the bond stress can be derived as

$$
\begin{aligned}
\tau_{1} & =\frac{P_{\mathrm{u}}}{\pi d_{\mathrm{b}} l_{1}}=\frac{f_{\mathrm{u}} d_{\mathrm{b}}}{4 l_{1}}=\frac{f_{\mathrm{tk}} c s_{\mathrm{v}}+0.5 \pi \sigma_{\mathrm{s}} d_{\mathrm{sb}}^{2}}{d_{\mathrm{b}} s_{\mathrm{v}}\left(\left(1 / \tan \alpha_{1}\right)+\left(1 / \tan \alpha_{2}\right)\right)} \\
& =\frac{f_{\mathrm{tk}} c s_{\mathrm{v}}+0.5 \pi \sigma_{\mathrm{s}} d_{\mathrm{sb}}^{2}}{2 d_{\mathrm{b}} s_{\mathrm{v}}} .
\end{aligned}
$$

Substituting the test bond strength $\left(\tau_{\mathrm{b}}\right)$ in equation (8), the tensile stress of the spiral reinforcement when the splice failed by bond can be calculated, as listed in Table 3. It is seen that all the calculated stresses of $\sigma_{\mathrm{s}}$ are less than the specified yield strength of $300 \mathrm{MPa}$.

As the lap length increases, dramatic decrease in the spiral bar stress can be observed. Taking the splices of C4018-x-4-75 series as an example, as the lap length increases from $0.8 l_{\mathrm{aE}}$ to $1.2 l_{\mathrm{aE}}$, the $\sigma_{\mathrm{s}}$ decreases by $61.6 \%$, from 226.0 MPa to $86.8 \mathrm{MPa}$. Meanwhile, for the $18 \mathrm{~mm}$ bar splices, comparing d6@100 splices with d4@50 splices, it can be found that by reducing the volumetric stirrup ratio from $1.62 \%$ to $1.44 \%$, the spiral bar stress and the tensile strength of lapping bar increase averagely $35.1 \%$ and $5.4 \%$, respectively. This indicates a more effective confinement provided by the spiral of $\mathrm{d} 4 @ 50$. In general, it can be concluded that (i) as the lap length increases, the effect of spiral reinforcement declines and (ii) under the premise of similar volumetric stirrup ratios, smaller spiral bar and pitch distance can improve the material utilization of the spiral and achieve a higher tensile strength.

\section{Design Method and Recommendation}

According to ACI 318-14 [2], with an appropriate simplification, the development length $l_{\mathrm{d}}$ needed to develop stress $f_{\mathrm{s}}$ in a deformed bar may be expressed as

$$
l_{\mathrm{d}}=\left(\frac{f_{\mathrm{s}}}{1.1 \sqrt{f_{\mathrm{c}}^{\prime}}\left(\left(c+K_{\mathrm{tr}}\right) / d_{\mathrm{b}}\right)}\right) d_{\mathrm{b}} .
$$

In equation (9), terms are defined and values are established as follows: Ktr is the transverse reinforcement index: $K_{\mathrm{tr}}=40 A_{\mathrm{tr}} / n s_{\mathrm{v}} ; A_{\mathrm{tr}}$ is the total cross-sectional area of all transverse reinforcement within spacing $s_{\mathrm{V}}$ that crosses the potential plane of splitting through the reinforcement being developed; $n$ is the number of bars being developed along the plane of splitting; and $f_{c}^{\prime}$ is the specified compressive strength of concrete. For full development of the bar, $f_{\mathrm{s}}$ is set equal to the specified yield strength $f_{\mathrm{byk}}$, and the term $\left(c+K_{\mathrm{tr}}\right) / d_{\mathrm{b}}$ should not be taken greater than 2.5 .

Nevertheless, for the precast concrete structures, the main bars usually spliced in the potential plastic hinge for construction convenience. To ensure sufficient strength and 
TABLE 3: Calculated tensile stress of spiral reinforcement.

\begin{tabular}{|c|c|c|c|c|c|c|c|c|}
\hline Specimens & $l_{1, \exp }(\mathrm{mm})$ & $D_{\mathrm{s}}(\mathrm{mm})$ & $c(\mathrm{~mm})$ & $\rho_{\text {sv }}(\%)$ & Failure mode* & $f_{\mathrm{u}}(\mathrm{MPa})$ & $\tau_{\mathrm{b}}(\mathrm{MPa})$ & $\sigma_{\mathrm{s}}(\mathrm{MPa})$ \\
\hline C40-16-0.8-6-100 & 384 & 65 & 28 & 1.74 & $\mathrm{BP}(3)$ & 548.1 & 5.71 & 90.6 \\
\hline C40-16-0.8-6-75 & 384 & 65 & 28 & 2.32 & BP (2) & 598.1 & 6.23 & 90.1 \\
\hline C40-16-0.8-4-75 & 384 & 65 & 28 & 1.03 & $\mathrm{BP}(2)$ & 579.3 & 6.03 & 184.0 \\
\hline C40-16-0.8-4-50 & 384 & 65 & 28 & 1.55 & BP (1) & 598.0 & 6.23 & 135.0 \\
\hline C40-16-1.0-6-100 & 480 & 65 & 28 & 1.74 & $\mathrm{BP}(3)$ & 572.5 & 4.77 & 37.5 \\
\hline C40-16-1.0-6-75 & 480 & 65 & 28 & 2.32 & $\mathrm{BP}(1)$ & 601.5 & 5.01 & 38.4 \\
\hline C40-16-1.0-4-75 & 480 & 65 & 28 & 1.03 & $\mathrm{BP}(2)$ & 590.7 & 4.92 & 77.8 \\
\hline C40-16-1.0-4-50 & 480 & 65 & 28 & 1.55 & $\mathrm{BP}(1)$ & 603.4 & 5.03 & 58.6 \\
\hline C40-18-0.8-6-100 & 432 & 70 & 25 & 1.62 & $\mathrm{BP}(3)$ & 495.7 & 5.16 & 117.4 \\
\hline C40-18-0.8-6-75 & 432 & 70 & 25 & 2.15 & $\mathrm{BP}(3)$ & 575.8 & 6.00 & 127.9 \\
\hline C40-18-0.8-6-50 & 432 & 70 & 25 & 3.23 & $\mathrm{BP}(2)$ & 612.3 & 6.38 & 97.4 \\
\hline C40-18-0.8-4-75 & 432 & 70 & 25 & 0.96 & $\mathrm{BP}(3)$ & 520.6 & 5.42 & 226.0 \\
\hline C40-18-0.8-4-50 & 432 & 70 & 25 & 1.44 & $\mathrm{BP}(3)$ & 544.7 & 5.67 & 168.6 \\
\hline C40-18-1.0-6-100 & 540 & 70 & 25 & 1.62 & $\mathrm{BP}(3)$ & 573.5 & 4.78 & 92.9 \\
\hline C40-18-1.0-6-75 & 540 & 70 & 25 & 2.15 & $\mathrm{BP}(2)$ & 613.4 & 5.11 & 85.6 \\
\hline C40-18-1.0-4-75 & 540 & 70 & 25 & 0.96 & $\mathrm{BP}(3)$ & 584.7 & 4.87 & 166.8 \\
\hline C40-18-1.0-4-50 & 540 & 70 & 25 & 1.44 & BP (3) & 593.4 & 4.95 & 116.4 \\
\hline C40-18-1.2-6-100 & 648 & 70 & 25 & 1.62 & BP (3) & 594.0 & 4.13 & 51.3 \\
\hline C40-18-1.2-6-75 & 648 & 70 & 25 & 2.15 & $\mathrm{BP}(1)$ & 617.7 & 4.29 & 46.3 \\
\hline C40-18-1.2-4-75 & 648 & 70 & 25 & 0.96 & $\mathrm{BP}(3)$ & 594.4 & 4.13 & 86.8 \\
\hline C40-18-1.2-4-50 & 648 & 70 & 25 & 1.44 & BP (1) & 615.6 & 4.28 & 68.4 \\
\hline
\end{tabular}

${ }^{*} \mathrm{BP}(n)$ represents bar pullout failure and the figure in the parenthesis is the number of the bond failure specimens.

displacement ductility in the connection region and realize a full-yield strength of the bar, 50 percent increase above the specified yield strength was selected according to ACI 550.1R [10]. Furthermore, because the bars are usually lapped at the same section of high tensile stress, the length of $l_{\mathrm{d}}$ should be multiplied by 1.3 according to ACI $318-14$. As a result, the lap length $l_{1}$ can be written as

$$
l_{1, \mathrm{cal}}=\varphi\left(\frac{1.95 f_{\mathrm{byk}}}{1.1 \sqrt{f_{\mathrm{c}}^{\prime}}\left(\left(c+K_{\mathrm{tr}}\right) / d_{\mathrm{b}}\right)}\right) d_{\mathrm{b}},
$$

where $\varphi$ is a reduction factor. It should be noted that the upper limit of 2.5 for the term $\left(c+K_{\mathrm{tr}}\right) / d_{\mathrm{b}}$ seems too conservative according to the test results in this paper. For example, the tensile strength of specimen d6@50 is distinctively improved compared with that of corresponding specimen configured with d4@50 by virtue of the higher confinement, although the calculated values of $\left(c+K_{\mathrm{tr}}\right) / d_{\mathrm{b}}$ are greater than 2.5. Consequently, equation (10) may be used with a recommendation to increase the limit to 4.0 instead of $2.5[7,17,18]$.

The value of $\varphi$ can be obtained by the statistical method. The sequence for adopting the required lap length $\left(l_{1}\right)$ and its frequency $\left(n_{\mathrm{fl}}\right)$ is outlined in Figure 9. Substituting the lap length in equation (10), the factor $\varphi$ and its fitted probability distribution are derived and shown graphically in Figure 10. Assuming that $\varphi$ is normally distributed, the mean value and standard deviation are 0.645 and 0.073 , respectively. As a result, a $95 \%$ confidence value of 0.76 is adopted, and equation (10) can be expressed as

$$
l_{\mathrm{l}, \mathrm{cal}}=\left(\frac{1.35 f_{\mathrm{byk}}}{\sqrt{f_{\mathrm{c}}^{\prime}}\left(\left(c+K_{\mathrm{tr}}\right) / d_{\mathrm{b}}\right)}\right) d_{\mathrm{b}},
$$

where $\left(c+K_{\mathrm{tr}}\right) / d_{\mathrm{b}}$ should not exceed 4.0 . The calculated lap lengths $l_{1, \text { cal }}$ are listed in Table 4 . The criterion for determining the experimental minimum lap length $l_{1, \exp }$ of the specimens with the same spiral configuration in Table 4 is that the tensile strengths of the three specimens are all not less than $150 \%$ of $f_{\text {byk }}$. It can be seen that with the exception of specimens C40-16-x-6-75, all the calculated/experimental ratios $l_{1, \text { cal }} / l_{1, \exp }$ are greater than 1.0 , which shows an reliable prediction. For the specimens C40-16-0.8-6-75, only one specimen does not meet the above length adopting criteria with a slightly lower tensile strength, as shown in Table 2. That means the required lap length may be a little higher than $384 \mathrm{~mm}\left(0.8 l_{\mathrm{aE}}\right)$, but less than the value of $480 \mathrm{~mm}\left(1.0 l_{\mathrm{aE}}\right)$ in the table. Consequently, the predicted $l_{1, \text { cal }}$ should be more close to or higher than the actual minimum lap length.

Moreover, considering that the spirals are inexpensive [7], the upper limit of 4.0 for the term $\left(c+K_{\mathrm{tr}}\right) / d_{\mathrm{b}}$ can be used to determine the minimum amount of spiral reinforcement for a simplification. And then, evaluation of equation (11) results in

$$
l_{\mathrm{l}, \mathrm{cal}}=\left(\frac{0.34 f_{\mathrm{byk}}}{\sqrt{f_{\mathrm{c}}^{\prime}}}\right) d_{\mathrm{b}} .
$$

It should be noted that the above equation for estimating the required lap length of deformed bar in spirally confined connection is based on the bar with $16 \mathrm{~mm}$ and $18 \mathrm{~mm}$ diameter and additional testing is recommended to confirm the performance of spirally confined lap splice for other diameters. It is also important to experimentally evaluate the performance of the proposed lap splice under cyclic loading and in a full-scale setting (e.g., connecting wall panels) when necessary before implementation to ensure adequate performance based on application requirements. 


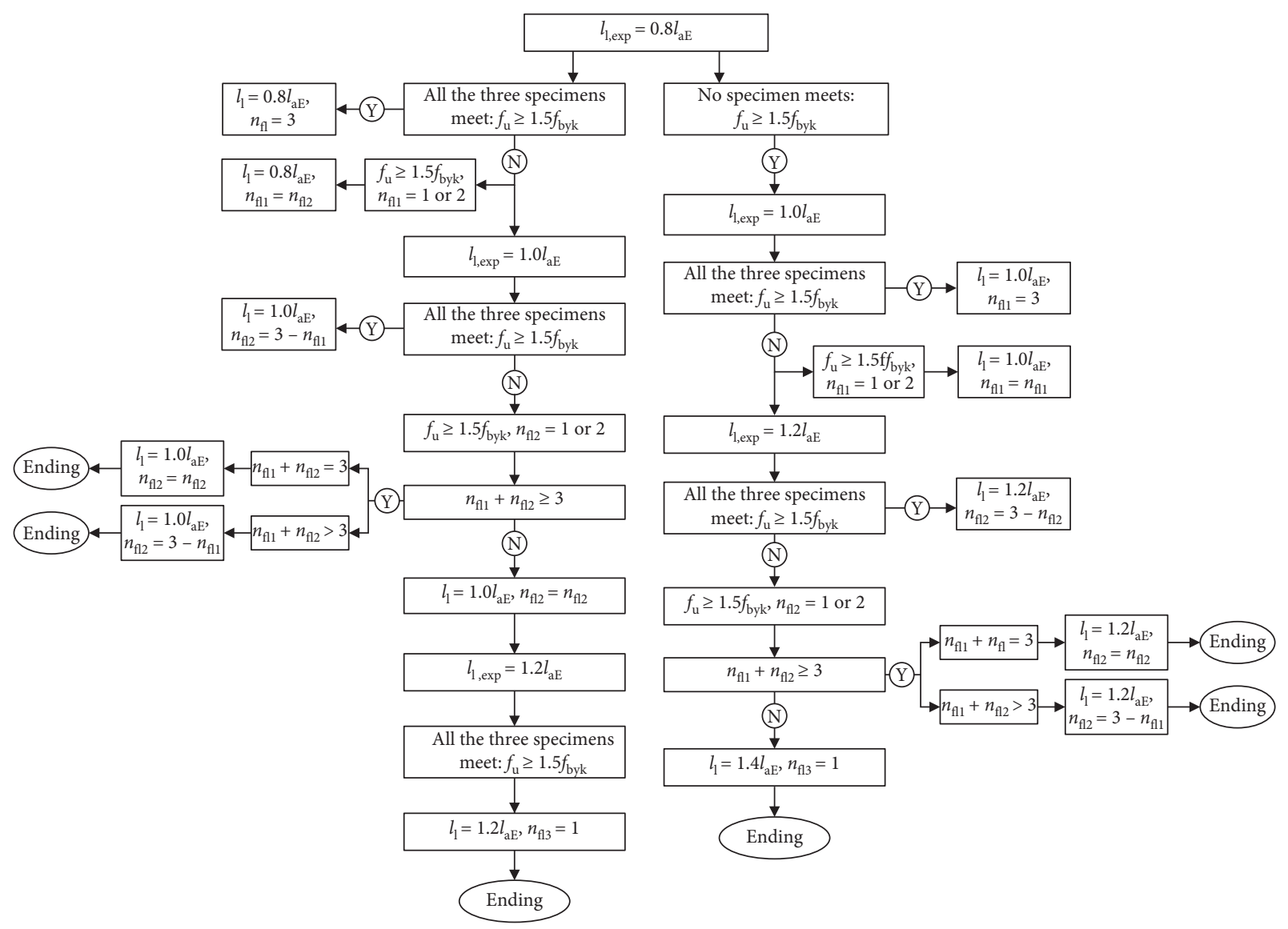

FIgURE 9: Experimental lap length adopting sequence.

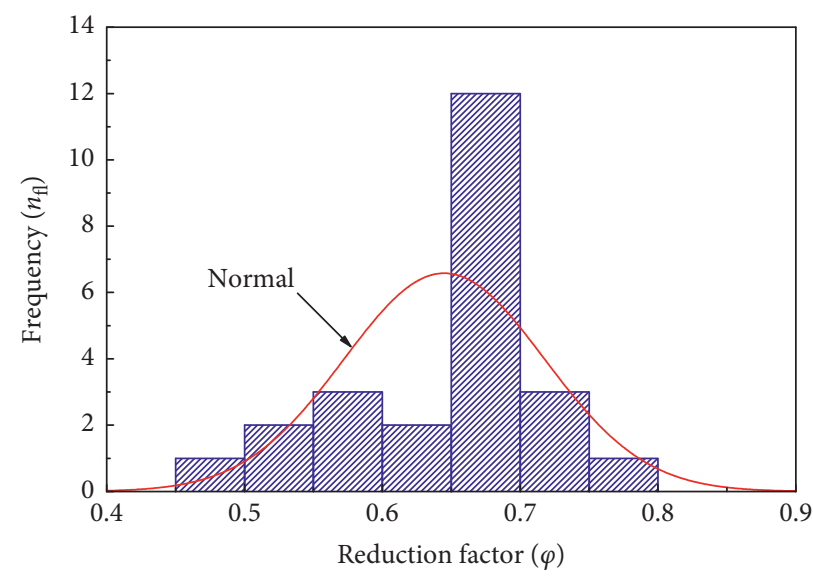

FiguRE 10: Fitted normal distribution of the reduction factor.

TABLE 4: Comparison of lap lengths.

\begin{tabular}{|c|c|c|c|c|c|c|}
\hline Specimens & $A_{\mathrm{sb}}\left(\mathrm{mm}^{2}\right)$ & $K_{\mathrm{tr}}(\mathrm{mm})$ & $\left(c+K_{\mathrm{tr}}\right) / d_{\mathrm{b}}$ & $l_{1, \exp }(\mathrm{mm})$ & $l_{1, \mathrm{cal}}(\mathrm{mm})$ & $l_{1, \mathrm{cal}} / l_{1, \exp }$ \\
\hline$C 40-16-x-6-50$ & 56.5 & 22.62 & 4.00 & 384 & 414 & 1.08 \\
\hline C40-16-x-6-75 & 56.5 & 15.08 & 3.60 & 480 & 460 & 0.96 \\
\hline$C 40-16-x-4-50$ & 25.1 & 10.05 & 2.98 & 480 & 557 & 1.16 \\
\hline C40-16-X-4-75 & 25.1 & 6.70 & 2.56 & 576 & 648 & 1.13 \\
\hline C40-18-x-6-50 & 56.5 & 22.62 & 3.90 & 432 & 478 & 1.11 \\
\hline C40-18-x-6-75 & 56.5 & 15.08 & 3.06 & 540 & 608 & 1.13 \\
\hline$C 40-18-x-4-50$ & 25.1 & 10.05 & 2.51 & 648 & 744 & 1.15 \\
\hline$C 40-18-x-4-75$ & 25.1 & 6.70 & 2.13 & 756 & 874 & 1.16 \\
\hline
\end{tabular}




\section{Conclusion}

The following conclusions can be drawn based on the test and analytical studies:

(1) For the spirally confined grout-filled lap splice, the bond failure usually featured by the pullout of the preembedded bar and the grouted bar, filler grout, and metal corrugated conduit can be regarded as a single body in the mechanical analysis.

(2) Increasing the volumetric ratio of spiral from $0.96 \%$ to $3.23 \%$ leads to an increment of $16 \%$ higher tensile strength, as demonstrated by the lapped splice with $18 \mathrm{~mm}$ bars and $24 d_{\mathrm{b}}$ bar embedded length. Meanwhile, the spiral reinforcement is generally difficult to yield, and reducing the spiral pitch distance is more effective to confine the filler grout compared with increasing the spiral bar diameter.

(3) Based on the equation of tensile development length in ACI 318-14, a modified equation of required lap length corresponding to the bar stress of $1.5 f_{\mathrm{byk}}$ is proposed. The calculated values show a reliable prediction compared to the experimental results.

\section{Nomenclature}

$A_{\text {tr }}: \quad$ Total cross-sectional area of all transverse reinforcement within spacing $s_{\mathrm{v}}$ that crosses the potential plane of splitting through the reinforcement being developed $\left(\mathrm{mm}^{2}\right)$

$C: \quad$ Clear cover of reinforcement $(\mathrm{mm})$

$d_{\mathrm{b}}$ : Nominal diameter of lap bar $(\mathrm{mm})$

$d_{\mathrm{c}}$ : $\quad$ Diameter of corrugated duct $(\mathrm{mm})$

$d_{\mathrm{sb}}$ : Nominal diameter of spiral bar $(\mathrm{mm})$

$D_{\mathrm{s}}$ : $\quad$ Spiral diameter $(\mathrm{mm})$

$f_{\text {by: }} \quad$ Design tensile strength of reinforcement ( $\left.\mathrm{MPa}\right)$

$f_{\text {byk }}$ : Specified tensile strength of reinforcement (MPa)

$f_{c}^{\prime}$ : Specified compressive strength of concrete ( $\left.\mathrm{MPa}\right)$

$f_{\mathrm{t}}$ : Design tensile strength of concrete $(\mathrm{MPa})$

$f_{\mathrm{tk}}$ : Specified tensile strength of concrete ( $\left.\mathrm{MPa}\right)$

$f_{\mathrm{u}}$ : $\quad$ Tensile strength of splice

$l_{\mathrm{aE}}: \quad$ Basic development length in tension

$l_{1, \mathrm{cal}}$ : Calculated lap length in tension of deformed bar

$l_{1, \exp }$ : Experimental lap length in tension of deformed bar

$n_{\mathrm{fl}}: \quad$ Frequency of required minimum lap length

$n_{\mathrm{ff}}$ : Frequency of tensile strength $f_{\mathrm{u}}$ which not less than $1.5 f_{\text {byk }}$

$s_{\mathrm{v}}: \quad$ Spiral pitch distance

$K_{\text {tr: }}: \quad$ Transverse reinforcement index

$P_{\mathrm{u} \text { exp }}$ : Experimental pullout load $(\mathrm{kN})$

$\alpha: \quad$ Reinforcement shape factor

$\rho_{\text {sv }}: \quad$ Volumetric spiral reinforcement ratio

$\zeta_{\mathrm{aE}}: \quad$ Correction factor reflecting the building aseismic grade

$\zeta_{\mathrm{a}}$ : Factor reflecting the effects of reinforcement size, epoxy coating, concrete cover, etc

$\tau_{\mathrm{b}}$ : $\quad$ Bond strength of lap bar

$\tau_{1}$ : $\quad$ Tangential stress at bar-concrete interface

$\sigma_{1}$ : Normal stress at bar-concrete interface $\tau_{2}$ : Tangential stress at conduit-concrete interface

$\sigma_{2}$ : Normal stress at conduit-concrete interface

$\varphi$ : $\quad$ Reduction factor of calculated lap length.

\section{Data Availability}

The data used to support the findings of this study are available from the corresponding author upon request.

\section{Conflicts of Interest}

The authors declare that they have no conflicts of interest.

\section{Acknowledgments}

This work was supported by the National Key Research and Development Program of China (grant nos. 2016YFC0701703 and 2016YFC0701705-1); a Project of Shandong Province Higher Educational Science and Technology Program (grant no. J17KA207), and the National Natural Science Foundation of China (grant nos. 51778632 and 51408614).

\section{References}

[1] JGJ1-2014, Technical Specification for Precast Concrete Structures, Chinese Industry Standard, China Architecture \& Building Press, Beijing, China, 2014, in Chinese.

[2] ACI318-14, Building Code Requirements for Structural Concrete and Commentary, American Concrete Institute, Farmington Hills, MI, USA, 2014.

[3] A. Belleri and P. Riva, "Seismic performance and retrofit of precast concrete grouted sleeve connections," PCI Journal, vol. 57, no. 1, pp. 97-109, 2012.

[4] V. Popa, A. Papurcu, D. Cotofana, and R. Pascu, "Experimental testing on emulative connections for precast columns using grouted corrugated steel sleeves," Bulletin of Earthquake Engineering, vol. 13, no. 8, pp. 2429-2447, 2015.

[5] J. F. Rave-Arango, C. A. Blandón, J. I. Restrepo, and F. Carmona, "Seismic performance of precast concrete column-to-column lap-splice connections," Engineering Structures, vol. 172, pp. 687-699, 2018.

[6] N. Tullini and F. Minghini, "Grouted sleeve connections used in precast reinforced concrete construction-experimental investigation of a column-to-column joint," Engineering Structures, vol. 127, pp. 784-803, 2016.

[7] A. Einea, S. Yehia, and M. K. Tadros, "Lap splices in confined concrete," ACI Structural Journal, vol. 96, no. 6, pp. 947-955, 1999.

[8] S. J. A. Hosseini and A. B. A. Rahman, "Effects of spiral confinement to the bond behavior of deformed reinforcement bars subjected to axial tension," Engineering Structures, vol. 112, pp. 1-13, 2016.

[9] T. K. Hassan, G. W. Lucier, and S. H. Rizkalla, "Splice strength of large diameter, high strength steel reinforcing bars," Construction and Building Materials, vol. 26, pp. 216-225, 2012.

[10] ACI550.1R-09, Emulating Cast-In-Place Detailing for Seismic Design of Precast Concrete Structures, American Concrete Institute, Farmington Hills, MI, USA, 2009.

[11] Precast and Prestressed Concrete Institute, PCI Design Handbook: Precast and Prestressed Concrete, Precast Prestressed Concrete Institute, Chicago, IL, USA, 2010. 
[12] GB 50010-2010, Code for Design of Concrete Structures, Chinese National Standards, China Architecture \& Building Press, Beijing, China, 2016, in Chinese.

[13] Y. Zheng, Z. Guo, J. Liu, X. Chen, and Q. Xiao, "Performance and confining mechanism of grouted deformed pipe splice under tensile load," Advances in Structural Engineering, vol. 19, no. 1, pp. 86-103, 2016.

[14] Y. Zheng, Z. Guo, D. Guan, and X. Zhang, "Parametric study on a novel grouted rolling pipe splice for precast concrete construction," Construction and Building Materials, vol. 166, pp. 452-463, 2018.

[15] R. I. Gilbert and A. E. Kilpatrick, "The strength and ductility of lapped splices of reinforcing bars in tension," Australian Journal of Structural Engineering, vol. 16, no. 1, pp. 35-46, 2015.

[16] R. Tepfers, "Cracking of concrete cover along anchored deformed reinforcing bars," Magazine of Concrete Research, vol. 31, no. 106, pp. 3-12, 1979.

[17] D. Darwin, M. L. Tholen, E. K. Idun, and J. Zuo, "Splice strength of high relative rib area reinforcing bars," $A C I$ Structural Journal, vol. 93, no. 1, pp. 95-107, 1996.

[18] D. Darwin, L. R. A. Lutz, and J. Zuo, "Recommended provisions and commentary on development and lap splice lengths for deformed reinforcing bars in tension," $A C I$ Structural Journal, vol. 102, no. 6, pp. 892-900, 2005. 


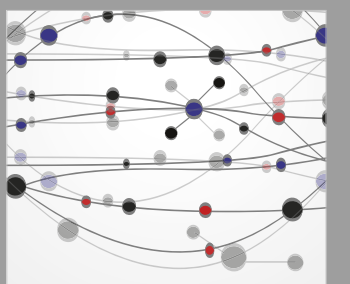

The Scientific World Journal
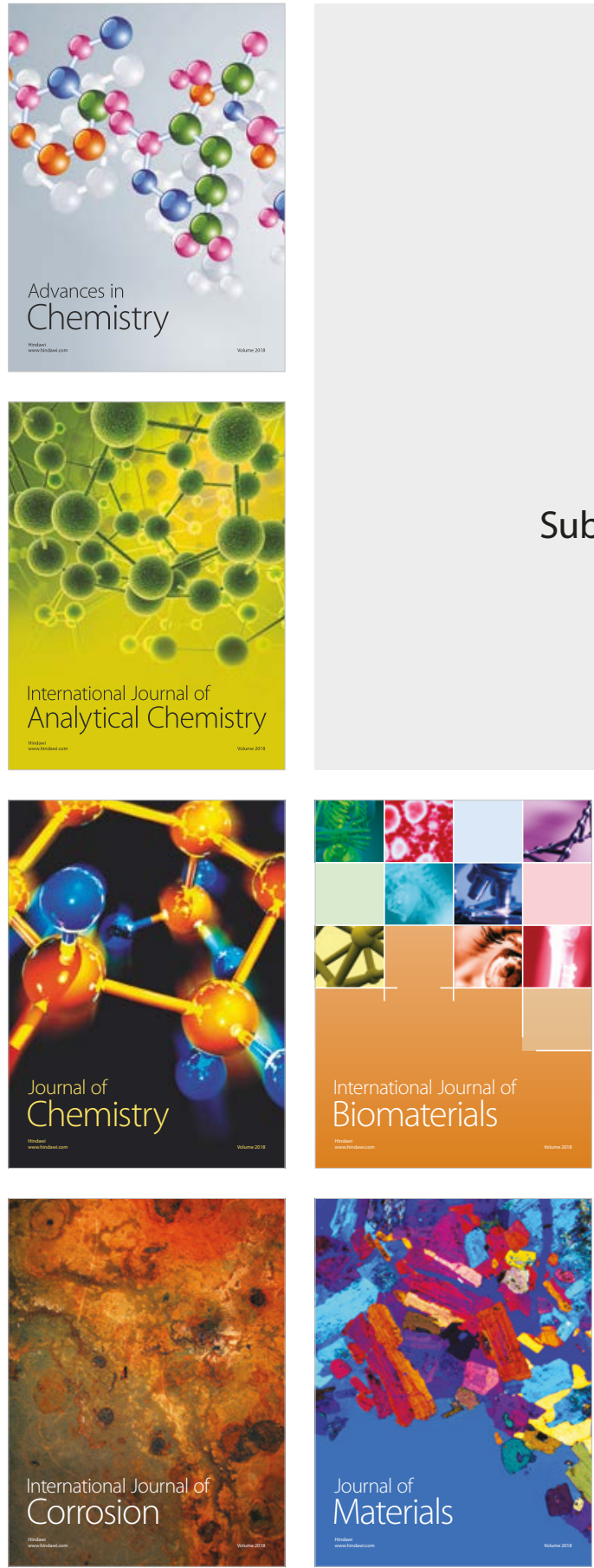

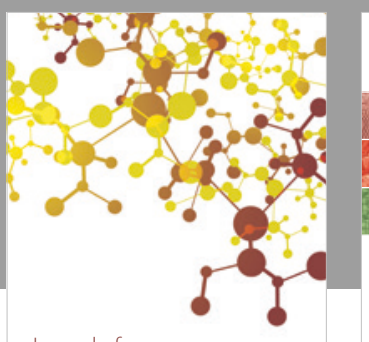

Journal of

Applied Chemistry
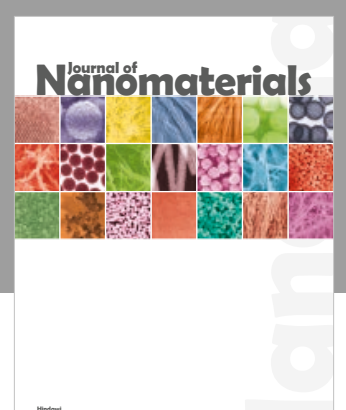

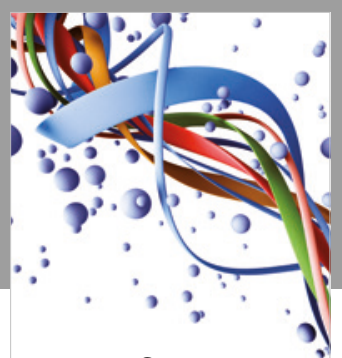

Scientifica

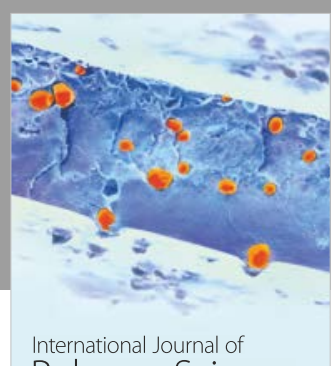

Polymer Science

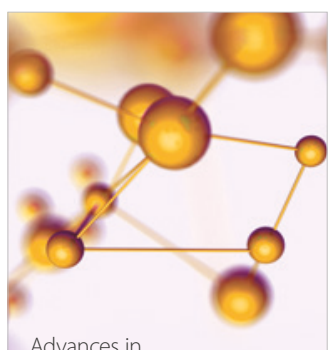

Physical Chemistry
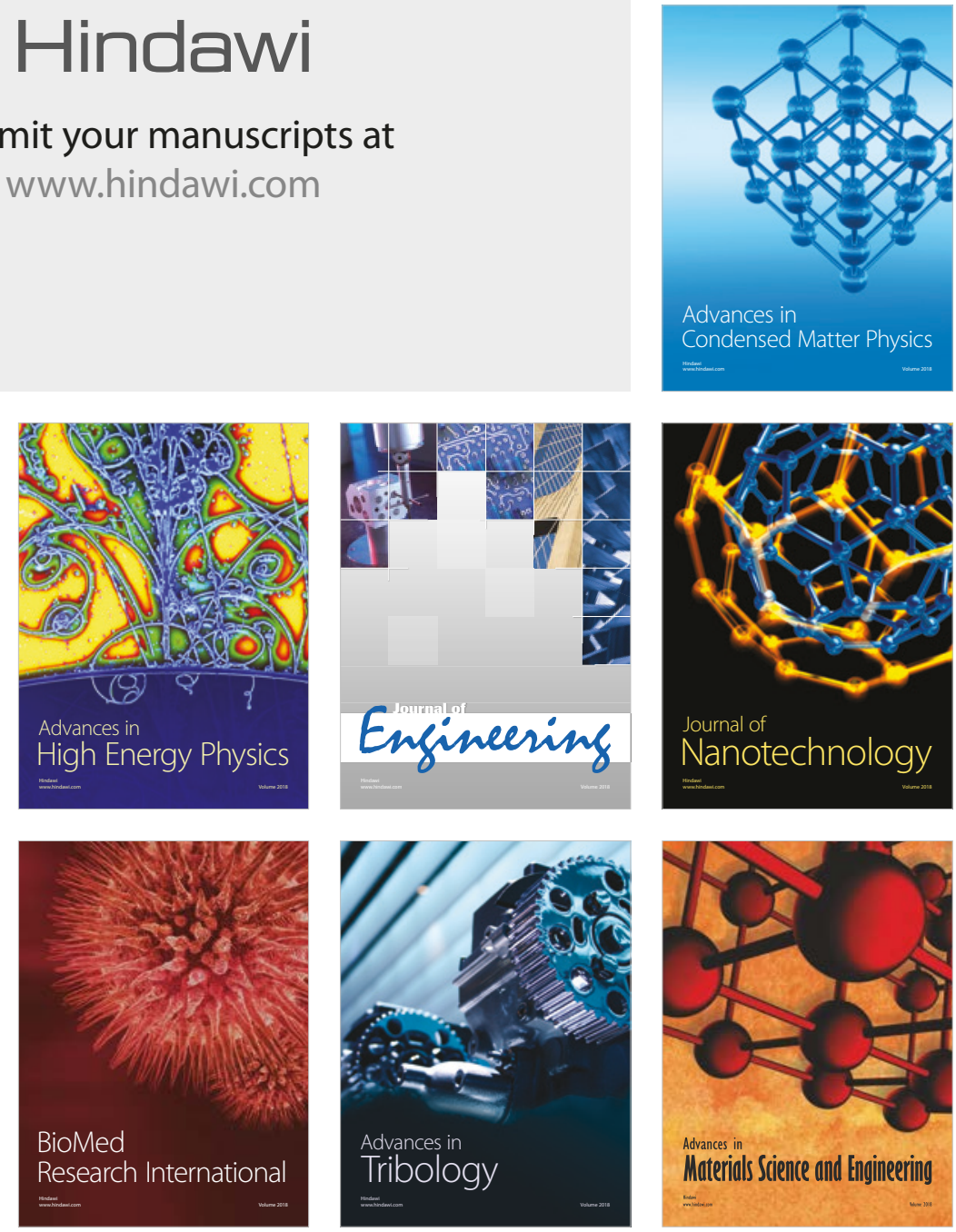